\title{
Interim Test Methods and Procedures for Determining the Performance of Small Photovoltaic Systems
}

P. McNutt, B. Kroposki, R. Hansen, and R. DeBlasio

National Renewable Energy Laboratory 1617 Cole Boulevard Golden, Colorado 80401-3393 A national laboratory of the U.S. Department of Energy Managed by Midwest Research Institute for the U.S. Department of Energy under Contract No. DE-AC36-83CH10093

Prepared under Task No. PV806301 July 1998 
This publication was reproduced from the best available camera-ready copy submitted by the subcontractor and received no editorial review at NREL.

\section{NOTICE}

This report was prepared as an account of work sponsored by an agency of the United Siates govemment. Neither the United States govemment nor any agency thereof, nor any of their employees, makes any warranty, express or implied, or assumes any legal liability or responsibility for the accuracy, completeness, or usefulness of any information, apparatus, product, or process disclosed, or represents that its use would not infringe privately owned rights. Reference herein to any specific commercial product, process, or service by trade name, trademark, manufacturer, or otherwise does not necessarily consitute or imply its endorsement, recommendation, or favoring by the United States govemment or any agency thereof. The views and opinions of authors expressed herein do not necessarily state or reflect those of the United States government or any agency thereof.

Available to DOE and DOE contractors from:

Office of Scientific and Technical Information (OSTI)

P.O. Box 62

Oak Ridge, TN 37831

Prices available by calling (423) 576-8401

Available to the public from:

National Technical Information Service (NTIS)

U.S. Department of Commerce

5285 Port Royal Road

Springfield, VA 22161

(703) $487-4650$ 


\section{Table of Contents}

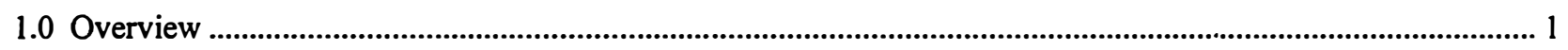

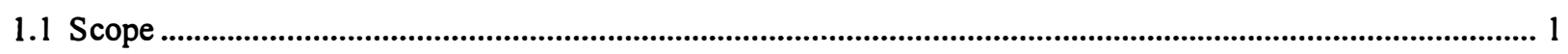

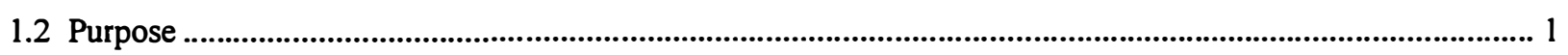

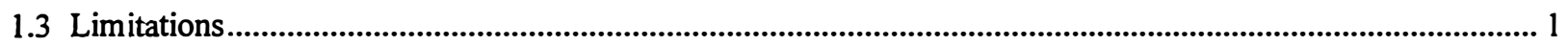

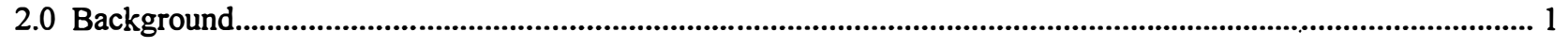

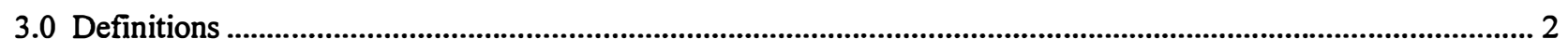

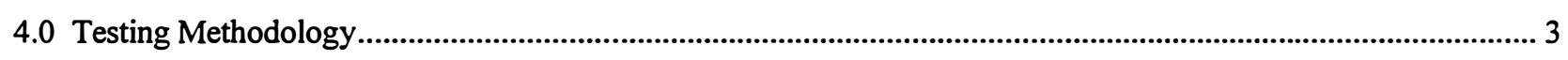

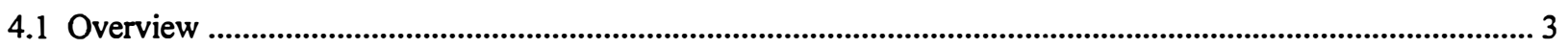

4.2 Recommended Instrumentation ................................................................................................................. 3

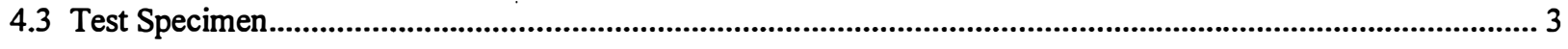

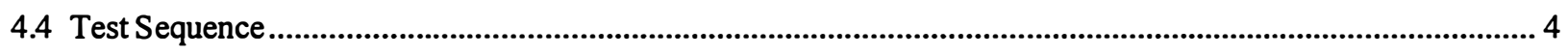

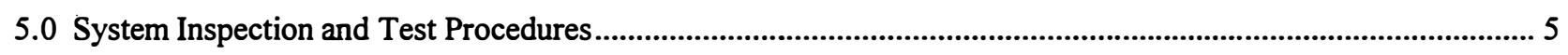

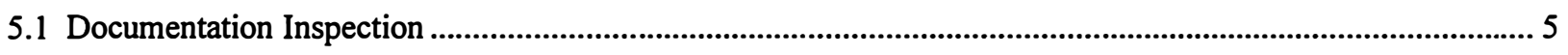

5.2 Preliminary System Inspection ............................................................................................................. 7

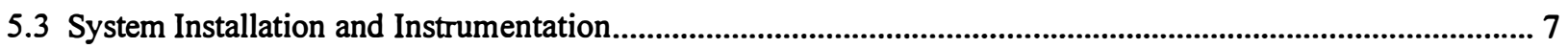

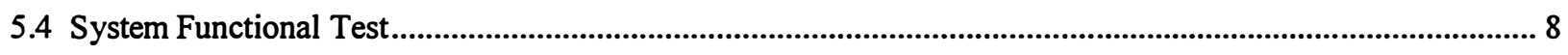

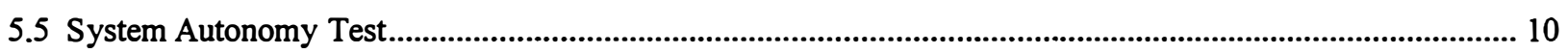

5.6 System Maintenance Procedure Review.................................................................................................... 11

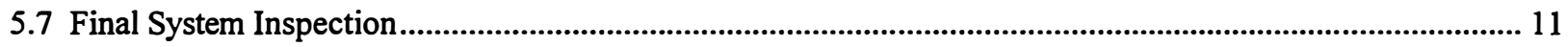

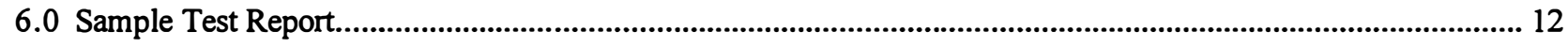

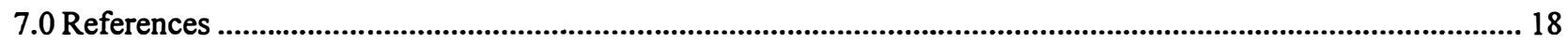

\section{List of Figures}

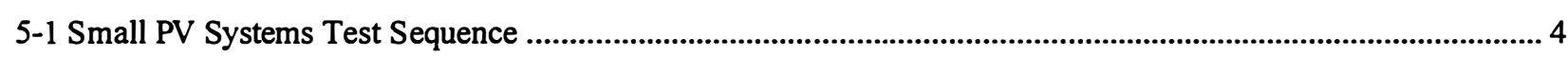




\subsection{Overview}

\subsection{Scope}

The test methods and procedures included in this document cover small (up to $5 \mathrm{~kW}$ ) stand-alone and utility-grid connected PV systems. The methodology covers complete system testing outdoors under prevailing conditions.

\subsection{Purpose}

This document provides test methods and procedures for determining the performance of small stand-alone and utility-grid connected PV systems. The procedures in this document provide a common approach for evaluating whether a given PV system is suitable to perform the function it was designed and manufactured to accomplish and meet the application load.

\subsection{Limitations}

The focus of the test methods and procedures in this document will be limited to complete system performance evaluations only. Individual sub-systems and components may be monitored, but only to evaluate the performance of the overall system.

These procedures do not address component or system reliability, quality issues, safety, or compliance to a regional or national mechanical or electrical code (e.g., NEC). These test methods and procedures do not cover PV-hybrid systems.

\subsection{Background}

Selection and validation, through type testing, of the appropriate design and construction of a PV system and its subsystems is a critical area of concern with regard to meeting and optimizing performance, operation and maintenance (O\&M), reliability, and safety. Over- or undersizing a system, inadequate subsystem and component selections, and improper interface matching have been concerns over the years with regard to meeting performance requirements and cost. Failure or reduced performance of systems due to exceeding the operational limits of subsystems and components within the system has led to misunderstandings regarding why the system failed to meet its application load requirements. Exaggerated performance expectations and marginal design limits have also led to failure in parts of the system and have increased O\&M system cost. Users must feel assured that a system will meet its intended design and application load requirements. This barrier to acceptance of PV systems can be reduced and eliminated with the proper tools one can reference for design and performance verification.

This test document fills a testing void and provides the catalyst and focus for establishing the technical foundation and bridging the institutional barriers needed to reduce uncertainty that a system's performance will be what its designers and builders claim. The need for this document was recently made more apparent with the initiation of a PV Global Approval Program (PVGAP) at the international level and is in response to concerns that PV systems being fielded must meet performance standards and that these standards include system-level performance type tests. The title of these test procedures is prefaced with the word "interim" because experience in using the procedures is needed before a consensus standard is developed and accepted by the PV community through its activities with the IEEE Standards Coordinating Committee 21 (SCC21) and International Electrotechnical Commission Technical Committee 82 (IEC TC82) national and international standards-making bodies. Both entities have initiated projects to develop test standards and will need the technical basis and validation of test procedures such as those presented in this document before a consensus is achieved by the PV community. 


\subsection{Definitions}

These terms are defined as used in this document $[1,4]$.

Array Disconnect Voltage (ADV) setpoint - The voltage set point of a charge controller at which the array is disconnected from the battery. This may also be referred to as the Voltage Regulation (VR) setpoint.

Array Reconnect Voltage (ARV) setpoint - The voltage set point of a charge controller at which the array is reconnected to the battery after reaching the array disconnect voltage.

Battery - A chemical device that stores electrical energy.

Capacity - The total number of amp-hours that can be withdrawn from a fully charged battery at a specific discharge rate and temperature, to a specific cutoff voltage.

Cell - The basic building block of a battery. Most batteries are composed of multiple cells to give a desired voltage and capacity.

Charge Controller - A device that protect the battery from overcharge and over-discharge. A charge controller may also monitor the system performance and provide system protection.

Inverter - A device that converts dc power to ac power.

Load - A device connected to an electrical system that consumes electrical power. Some systems may have multiple dc loads and multiple ac loads connected to an inverter.

Load Profile - The graphic representation of the energy consumed by the load as a function of time.

Load Reconnect Voltage (LRV) setpoint - The voltage set point of a device at which the load is reconnected to the battery after a low voltage disconnect occurred.

Low Voltage Disconnect (LVD) setpoint - The voltage set point of a device at which load is disconnected from the battery to prevent over-discharge of the battery.

Maximum Power Tracker - A device that electronically adjusts the current and voltage output of a PV array to maximize its power output.

Open-Circuit Voltage $\left(\mathbf{V}_{\text {oc }}\right)$ - The voltage at the output terminals of a device when no current is flowing in a circuit.

Power factor - A measure of the phase difference between ac voltage and ac current.

Power Quality - A measure of how well an ac signal compares with a pure sine wave.

Short-Circuit Current $\left(I_{s c}\right)$ - The current flowing between the shorted terminals of a PV device.

State of Charge (SOC) - The available capacity in a battery expressed as a percentage of its rated capacity.

System Autonomy - The period of time, usually defined in days, during which a fully charged battery can satisfy the load with no contribution from the PV array. 


\subsection{Testing Methodology}

\subsection{Overview}

PV systems will be tested for overall system functionality. The necessary instrumentation to perform the testing is described in Section 4.2. Test specimens are described in Section 4.3. The test sequence flow chart is provided in Section 4.4. Within the flow chart, there are specific tests that are then described in Section 5.0. A sample test report is provided in Section 6.0. The actual tests to be run will be determined based on the specific system to be tested and its loads. Examples of different types of PV systems are described in references [3,4, and 5].

\subsection{Recommended Instrumentation}

The following equipment is recommended for conducting the system tests:

- DC voltage sensor

- DC current sensor

- DC amp-hour meter

- Elapsed time meter

- AC voltage sensor - true RMS

- AC current sensor - true RMS

- AC power sensor - true RMS

- Pyranometer or reference cell

- Temperature sensors

- Battery hydrometer.

Additional equipment that may also be useful includes:

- AC spectrum analyzer capable of measuring harmonic content, waveform, and power factor

- I-V curve tracer

- Oscilloscope

- Automated data acquisition system (DAS) to facilitate long term system monitoring.

Each piece of equipment should be properly calibrated and of sufficient accuracy and resolution.

\subsection{Test Specimen}

One complete system is required for testing. The system should include documentation and all related parts for installation. Spare parts may be included in the event parts are damaged in shipment or during testing. 


\subsection{Test Sequence}

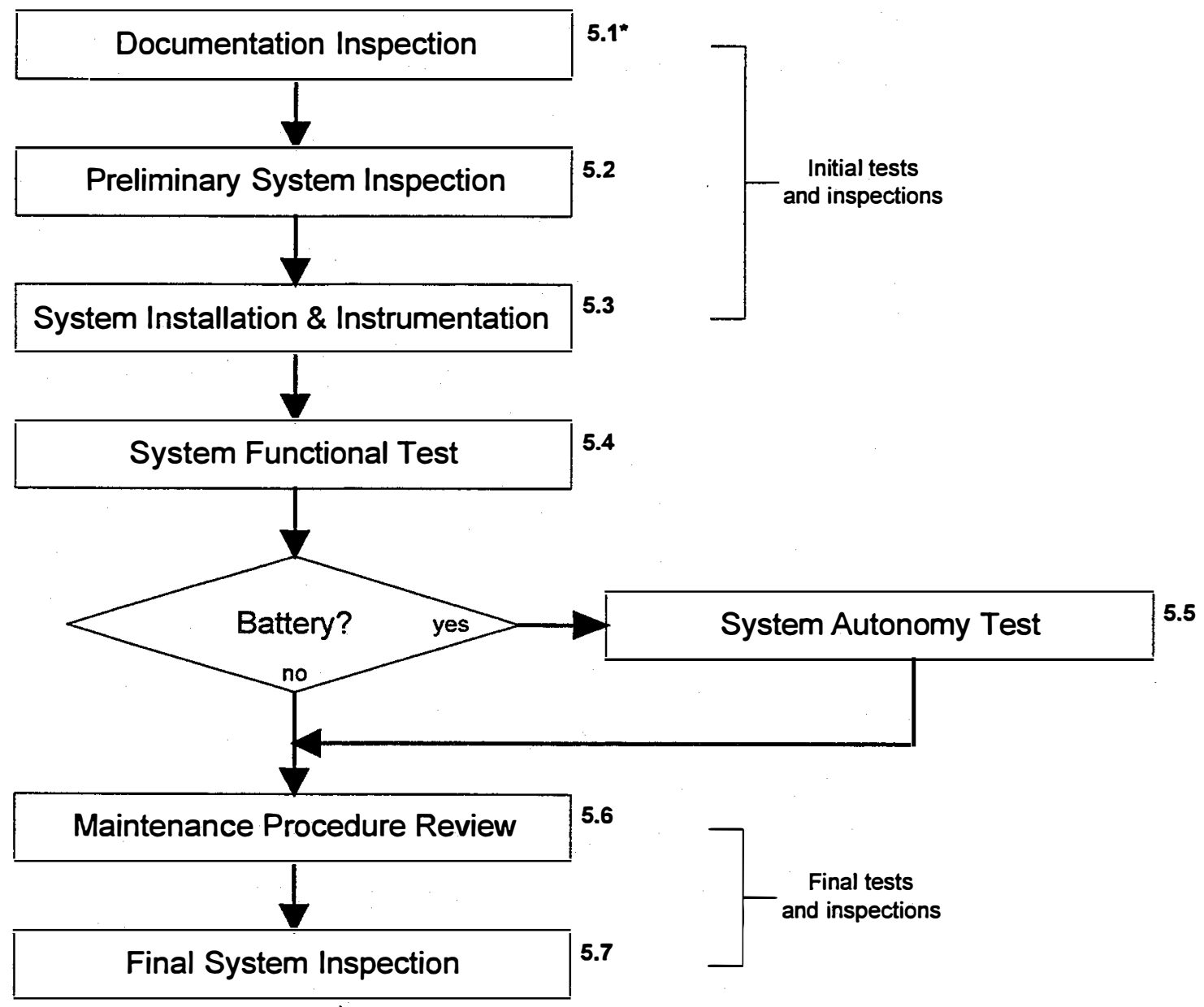

- Note: the number to the right of each box corresponds to the required test or inspection procedure.

Figure 5-1. Small PV Systems Test Sequence 


\subsection{System Inspection and Test Procedures}

In this section, not all of the following procedures and steps will apply to all systems. The actual tests to be run will be determined based on the specific system to be tested and its loads. All measurements, notes, comments, and calculations should be recorded in the test report (see the sample test report in Section 6.0).

\subsection{Documentation Inspection}

5.1.1 Inspect the documentation that comes with the system. List in the test report all documentation included with the system. All system documentation should be copied and included with the test report. The documentation may include the following items:

- System and load specifications

- Component specifications

- Parts list

- List of required components not included with the system

- Tool list

- Electrical schematic

- Installation instructions

- Operation instructions

- Maintenance instructions

- Troubleshooting instructions.

5.1.2 Read all documentation to verify system installation, operation, and maintenance can be performed.

5.1.3 Record the specifications for the system and each component in Part 2 of the test report. The system specifications may include the following for each applicable component:

System and Load (may be multiple dc and ac loads):

- Load manufacturer(s)

- Load model number(s)

- Load description(s)

- Typical load profile

- Nominal operating voltage (Vdc or Vac)

- Maximum/start current (A)

- Nominal current (A)

- Inverter idle-consumption power draw (W)

- Inverter continuous power output (W)

- Inverter surge power output (W)

- Hours of operation per day

- Amp-hours consumed by the load per day

- Days of autonomy. 
PV

- Module manufacturer

- Module model number

- Module material

- Array configuration (number of series and parallel modules)

- Array rated power (W)

- Array voltage at $P \max (\mathrm{V})$

- Array current at Pmax (A)

- Array open-circuit voltage (V)

- Array short-circuit current (A)

- Conditions at which above values are specified (e.g., irradiance, temperature)

- Tilt and range.

- Manufacturer

- Model number

- Type

- Battery bank configuration (number of series and parallel cells)

- Recommended battery initialization charge sequence

- Nominal battery voltage

- Nominal cell voltage

- Nominal battery capacity (Ah)

- Conditions at which above specifications were rated (e.g., temperature and discharge rate)

- Capacity vs. temperature chart or table

- SOC vs. specific gravity, or voltage, chart or table

- Recommended charge voltage and temperature

- Recommended temperature compensation coefficient

- Recommended equalization charge voltage and schedule

- Recommended LVD.

\section{Charge Controller:}

- Manufacturer

- Model number

- Type (on/off, shunt, series, PWM, etc.)

- Recommended connection sequence

- Maximum input voltage (V)

- Maximum input current (A)

- Maximum load current (A)

- Low-voltage disconnect (V)

- Array disconnect voltage (V)

- Temperature compensation coefficient $\left(\mathrm{V} /{ }^{\circ} \mathrm{C}\right)$

- Internal/external temperature compensation sensor.

An electrical schematic will be needed for determining the placement of the instrumentation. If one is not included with the system, an accurate schematic should be sketched and included in the test report. 


\subsection{Preliminary System Inspection}

Verify all system parts arrived undamaged.

5.2.1 Visually inspect the following system components for damage or obvious safety issues:

- PV Array

- Battery

- Load

- Inverter

- Charge controller

- Mounting Structure

- Wire

- Fuses, Disconnects, Protection Devices.

Note in the test report any damage or safety issues. It is up to the Tester, in consultation with the Requestor, to determine if any damage or safety issues are sufficient to discontinue testing, although the Tester may discontinue the tests if the system is considered unsafe.

5.2.2 Verify that all parts listed on the parts list are present. Note any missing system parts that should have been included. Any parts that are required but are not included with the system should be procured at this point.

\subsection{System Installation and Instrumentation}

Install the PV system per the installation instructions and install the instrumentation.

5.3.1 Follow the step-by-step system installation procedures provided with the documentation. The installation instructions should cover all steps of the system assembly. Note in the test report any missing steps or difficulties in following the instructions.

Caution should be used in installing the charge controller, as some need to be connected in a specified sequence to avoid damage.

While assembling the battery bank note and record in the test report the open-circuit voltage of each cell or battery. Note and record the overall battery open-circuit voltage. If the battery is received dry, follow the manufacturer's instructions for adding electrolyte and preconditioning the battery for system operation.

While assembling the PV array, measure and record the $\mathrm{V}_{\mathrm{oc}}$ and $\mathrm{I}_{\mathrm{sc}}$ of each module. Measure and record the overall array $\mathrm{V}_{\mathrm{oc}}$ and $\mathrm{I}_{\mathrm{sc}}$, POA irradiance, module temperature, local standard time in the test report.

It may be easier to install the instrumentation while assembling the system rather than waiting until afterwards.

5.3.2 Install the pyranometer or calibrated reference cell to measure the plane-of-array irradiance:

5.3.3 Install temperature sensors to measure the ambient temperature, back-of-module temperature, and battery temperature. The ambient temperature sensor should be in an aspirated shield to protect it from direct sun heating effects. The back-of-module temperature should be taken from the middle of a solar cell within the center of a module. The battery temperature sensor should be mounted as close as possible to the charge controller temperature compensation sensor. If temperature compensation is internal to the charge controller, a temperature sensor should be mounted on the controller.

5.3.4 Install voltage sensors for the PV array, battery, and dc and ac loads. To access hard-to-reach voltage drop measurements in Section 5.4, it may be necessary to run voltage extension leads to the array, battery, and load. 
5.3.5 Install current sensors for the PV array, battery, and dc and ac loads.

5.3.6 Install a true RMS wattmeter on the ac loads. DC power may be computed by multiplying dc voltage and current.

5.3.7 Install a sensor to detect proper load operation (e.g., a temperature sensor inside a refrigerator). The system should be instrumented to monitor the number of hours the load operates.

5.3.8 In the test report, record the data sample and storage rates (e.g., data measurements taken every 5 seconds, averaged and recorded every 15 minutes). List the measurements along with a brief description describing where each measurement is being taken and any multiplier factors. List each piece of test equipment and when it was last calibrated.

\subsection{System Functional Test}

Monitor the performance of the system under real-time outdoor prevailing conditions over the time period. The data collection period should consist of a cumulative POA insolation of at least $50 \mathrm{kWh} / \mathrm{m}^{2}$.

5.4.1 Allow the system to operate normally while monitoring the following:

- Combined dc loads voltage, current and power

- Combined ac loads voltage, current, and power (some systems may have multiple dc and ac loads)

- Battery voltage, current, and temperature

- Amp-hours into and out of the battery

- Array voltage and current

- POA irradiance

- Ambient temperature

- Back-of-module temperature

- Load output (e.g., lamp on).

If the load and load profile are not provided then the Tester and Requestor will need to agree upon one or several different realistic loads and profiles. If multiple loads and profiles are selected, it will be necessary to run the system functional test for each.

5.4.2 Record the date and time at which testing starts and ends.

5.4.3 Record the above parameters while operating the expected load according to its expected, or agreed upon, load profile. Data should be collected hourly at a minimum.

5.4.4 Verify the system and load are operating correctly by periodically monitoring the data. In systems with multiple loads, and if possible, start and run each individual $\mathrm{dc}$ and ac load while all other loads are operating. Record the results in the test report.

5.4.5 Note in the test report the magnitude of any current flowing through the array during the night.

5.4.6 If the system uses a maximum power tracker, record in the test report the array power, voltage and current at the irradiance which the modules are rated.

5.4.7 System Voltage Drops: Measure and record the voltage drops across the system during normal system operation. The voltage drops may include those measured between the PV array, load, and battery. During the daytime tests, the sky should be cloudless to minimize fluctuations in the charging current. Measurements should be made with a voltmeter capable of measuring down to the millivolt range. 


\section{Daytime Battery Charge Voltage Drops:}

Early in the battery recharging cycle, while there are no clouds obscuring the sun, and while the sun is near solar noon (to ensure the battery's charge current is nearly maximum), measure and record the dc voltage drops between the positive terminals from the array to the battery, and between the negative terminals from the array to the battery.

- Measure and record the terminal voltage at the array and at the battery.

- Record the array current at the start and end of the test.

- Record the time at which the test begins and ends.

During normal nighttime load operation, measure and record the dc voltage drops between the positive terminals from the battery to the load, and between the negative terminals from the battery to the load. For this test, the load will be defined as all combined dc loads plus the dc input to any inverters.

- Record the terminal voltage at the battery and the dc voltage at the load.

- Record the load current at the start and end of the test.

- Record the time at which the test begins and ends.

During normal daytime load operation measure and record the dc voltage drops between the positive terminals from the array to the load, and between the negative terminals from the array to the load.

- Record the terminal voltage at the array and at the load.

- Record the load current at the start and end of the test.

- Record the time at which the test begins and ends.

\subsubsection{Inverter}

If the ac loads can be unplugged from the inverter, unplug all ac loads and record the inverter dc idle consumption power. Reconnect the ac loads and verify the inverter resumes normal operation.

Verify ac motor loads start and run properly.

From the collected data, calculate and record the inverter efficiency at all discreet dc input current levels, where the efficiency is defined to be:

$$
\eta=P_{\mathrm{ac}} / \mathrm{P}_{\mathrm{dc}}
$$

Grid-connected inverters should meet IEEE 929 "Recommended Practice for Utility Interface of Residential and Intermediate Photovoltaic (PV) Systems" for over/under frequency and voltage set points and islanding disconnect times. Grid-connected inverters should also meet IEEE 519 "Recommended Practices and Requirements for Harmonic Control in Electric Power Systems" for harmonic content. Tests for determining over/under frequency and voltage set points, islanding disconnect times, and harmonic content are specified in IEEE P1373 (draft) "Recommended Practice for Field Test Methods and Procedures for Grid-connected Photovoltaic (PV) Systems."

5.4.9 Charge Controller Operation: From the collected data, record the maximum and minimum battery voltage levels, and the corresponding battery temperatures. If the controller employs temperature compensation, record the temperature at the temperature compensation sensor.

5.4.10 From the collected data, fill in all applicable test results in Part 2 of the test report.

5.4.11 Note in the test report any unusual occurrences during the test period. These may include unplanned short or open circuits, DAS malfunctions, etc. 


\subsection{System Autonomy Test}

The system autonomy test determines how long a fully charged battery can satisfy the system load with no contribution from the PV array $[2,6,7]$. This test should only be run after the system functional test and should only be run on systems with a battery protected by low-voltage disconnect (LVD) circuitry.

5.5.1 Initial Discharge: After having run the System Functional Test, Section 6.4, disconnect the PV array, and allow the load to fully discharge the battery. In this test, the battery will be defined as fully discharged when it reaches LVD. New lead acid batteries should not be discharged to LVD until after they have been conditioned according to the manufacturer's instructions. Some systems may have timers that will require special measures in order to run the load down to LVD.

5.5.2 Charge Cycle: Reconnect the PV array and disconnect the load. Monitor the battery voltage, current, amphours, and POA irradiance. Monitor the battery temperature as close as possible to the temperature compensation sensor. Allow the battery to fully charge. In this test the battery will be considered fully charged after the charge controller begins regulating the PV array energy, and after the battery has accepted $125 \%$ of its rated amp-hour capacity. Record the start and stop date and time. The data collection period should consist of a cumulative POA insolation of at least $50 \mathrm{kWh} / \mathrm{m}^{2}$. Record the amp-hours accepted by the battery. Calculate and record what percentage of the rated battery capacity was accepted by the battery:

$$
\text { (battery charge Ah / battery rated Ah) x 100\%. }
$$

Calculate and record, at least hourly, the POA insolation during this charge period.

5.5.3 Charged SOC: Disconnect the array and load and allow the battery to rest (neither charged nor discharged) for one hour. Measure and record the battery voltage, temperature, and specific gravity. Specific gravity can only be measured in serviceable flooded batteries. In this test, the battery initial SOC is determined from the battery open-circuit voltage or specific gravity after a one hour rest period (battery is neither charged nor discharged). Refer to the battery manufacturer's information to determine the SOC from the voltage or specific gravity, and battery temperature.

5.5.4 Discharge Cycle: Reconnect the load and record the amp-hours that are withdrawn from the battery until the charge controller reaches LVD. Record this number as the usable battery amp-hour capacity. Record the LVD voltage level. Record the start and stop date and time, and the cumulative time. Usable battery capacity is a function of battery temperature: consult the battery manufacturer's information for the temperature dependence. Calculate and record what percentage of the rated battery capacity was withdrawn from the battery:

$$
\text { (battery discharge } \mathrm{Ah} / \text { battery rated } \mathrm{Ah} \text { ) } \times 100 \% \text {. }
$$

5.5.5 SOC: Disconnect the array and load for one hour. Measure and record the voltage, specific gravity, and temperature of the fully discharged battery.

5.5.6 Compute and record the System Autonomy as the withdrawn amp-hours divided by the number of amp-hours the load should withdraw each day under normal system operation:

battery discharge Ah / (load runtime x load current)

or

hours to discharge battery / load runtime per day in hours. 


\subsection{System Maintenance Procedure Review}

This review is meant to point out any difficulties in performing system maintenance (e.g., having to disassemble the battery bank in order to check battery electrolyte levels). Read the manufacturer recommended maintenance procedures. Note in the test report if the procedures are clear and any difficulties that might occur in performing the maintenance procedures.

\subsection{Final System Inspection}

5.7.1 Visually inspect the system, noting any problems or damage in the test report. The inspection should include the following items:

- PV Array

- Battery

- Loads

- Inverter

- Charge controller

- Mounting structure

- Wire

- Fuses, disconnects, protection devices.

5.7.2 Flex all conductors along their entire length noting any discoloration or brittleness of the insulation. Undersized conductors and poor connections will tend to overheat, leading to brittle and discolored insulation. 


\subsection{Sample Test Report}

At the completion of the testing, the test report is filled out by the Testor and submitted to the Requester. What follows is a sample test report. The actual tests to be run will be determined based on the specific system to be tested and its loads.

The test report is divided into two parts. Part 1 can be thought of as a checklist where information or results are filled in sequentially from the test procedures. Part 2 is provided so a comparison can be made between the manufacturers' specifications and the measured results. Begin filling in Part 1 of the test report. While inspecting the documentation, fill in as much of Part 2 as possible. Manufacturers' specifications are primarily written in the left column. The measured results are written in the right column during or after system tests. 


\section{Test Report - Part 1 - Results}

Testing Laboratory:

Accredited by:

Begin Test Date:

Tester:

Requestor:

End Test Date:

\section{Brief System Description and Sketch}

\section{Documentation Inspection}

System Specifications (Y/N):

Component Specifications $(\mathrm{Y} / \mathrm{N})$ :

Parts List $(\mathrm{Y} / \mathrm{N})$ :

Parts-Not-Included List $(\mathrm{Y} / \mathrm{N})$ :

Tool List $(\mathrm{Y} / \mathrm{N})$ :

Electrical Schematic $(\mathrm{Y} / \mathrm{N})$ :

Installation Instructions $(\mathrm{Y} / \mathrm{N})$ :

Operating Instructions $(\mathrm{Y} / \mathrm{N})$ :

Maintenance Instructions $(\mathrm{Y} / \mathrm{N})$ :

Troubleshooting Instructions $(\mathrm{Y} / \mathrm{N})$ :

\section{Preliminary System Inspection}

Date \& Time:

Missing Parts or Components:

Damage:

Observations/Notes:

\section{Installation}

Start Date \& Time:

End Date \& Time:

Installers:

Instructions complete?:

Instructions easy to follow?:

Special tools required for system assembly:

Observations/Notes:

\section{Instrumentation \& Data Collection}

List of Test Equipment:

Instrument

$\underline{\text { Range }}$

Accuracy

$\underline{\text { Date of Last Calibration }}$

Calibrated By

List of Measurements:

$\underline{\text { Measurement }}$

Units Conversion Factor Description

Data Sample Rate:

Data Storage Rate: 


\section{System Functional Test}

Start Test Date \& Time: End Test Date \& Time:

Cumulative POA Insolation $\left(\mathrm{kWh} / \mathrm{m}^{2}\right)$ :

DC Loads Start \& Run Properly $(\mathrm{Y} / \mathrm{N})$ :

AC Loads Start \& Run Properly (Y/N):

Observations/Notes/Calculations:

\section{Daytime Battery Charge Voltage Drops}

Start Date \& Time:

Start PV Array Current (A):

Array Voltage (V):

Array V+ to Battery V+ (V):

Array V-to Battery V- (V):

Battery Voltage (V):

End PV Array Current (A):

End Time:

\footnotetext{
Nighttime/Discharge Voltage Drops

Start Date \& Time:

Start Load Current $\left(\mathrm{A}_{\mathrm{dc}}\right)$ :

Battery Voltage (V):

Battery $\mathrm{V}+$ to Load $\mathrm{V}+\left(\mathrm{V}_{\mathrm{dc}}\right)$ :

Battery V- to Load V- $\left(\mathrm{V}_{\mathrm{dc}}\right)$ :

Load Voltage $\left(\mathrm{V}_{\mathrm{dc}}\right)$ :

End Load Current $\left(\mathrm{A}_{\mathrm{dc}}\right)$ :

End Time:
}

\section{Daytime Load Voltage Drops}

Start Date \& Time:

Start Load Current $\left(A_{d c}\right)$ :

Array Voltage (V):

Array $\mathrm{V}+$ to Load $\mathrm{V}+\left(\mathrm{V}_{\mathrm{dc}}\right)$ :

Array V-to Load V- $\left(\mathrm{V}_{\mathrm{dc}}\right)$ :

Load Voltage $\left(\mathrm{V}_{\mathrm{dc}}\right)$ :

End Load Current $\left(\mathrm{A}_{\mathrm{dc}}\right)$ :

End Time: 


\section{System Autonomy Test}

Battery Rated Capacity (Ah):

Charge Cycle

Start Date \& Time:

Start Ah:

Cumulative Ah:

$\%$ of Rated Battery Capacity:

Cumulative Hours or Days:

Battery Maximum Voltage (V):

End Date \& Time:

End Ah:

Battery Temperature $\left({ }^{\circ} \mathrm{C}\right)$ :

Cumulative POA Insolation $\left(\mathrm{Wh} / \mathrm{m}^{2}\right)$ :

\begin{tabular}{ll}
\hline \multicolumn{1}{|c|}{ SOC after Battery Charge } \\
\hline Voc (V): & Date \& Time: \\
Specific Gravity: & Battery Temperature $\left({ }^{\circ} \mathrm{C}\right):$ \\
SOC (\%): &
\end{tabular}

\begin{tabular}{ll}
\hline \multicolumn{1}{|c|}{ Discharge Cycle } \\
\hline Start Date \& Time: & End Date \& Time: \\
$\begin{array}{l}\text { Start Ah: } \\
\text { Cumulative Ah: }\end{array}$ & End Ah: \\
\% of Rated Battery Capacity: & Battery Temperature $\left({ }^{\circ} \mathrm{C}\right):$ \\
$\begin{array}{l}\text { Cumulative Hours or Days: } \\
\text { Battery Minimum Voltage }(\mathrm{V}):\end{array}$ & Cumulative POA Insolation $\left(\mathrm{Wh} / \mathrm{m}^{2}\right):$ \\
\hline \multicolumn{1}{|c|}{ SOC after Battery Discharge } & \\
\hline Voc (V): & Date \& Time: \\
Specific Gravity: & Battery Temperature $\left({ }^{\circ} \mathrm{C}\right):$ \\
SOC (\%): & \\
\hline
\end{tabular}

\section{Calculate System Autonomy}

Expected System Autonomy:

Measured System Autonomy:

\section{System Maintenance Procedure Review}

Maintenance procedures are easy to understand?:

Maintenance procedures can be performed with no unnecessary difficulties?:

\section{Final System Inspection Notes}

Date \& Time:

Array:

Battery:

Loads:

Charge controller:

Mounting structure:

Wire (insulation discolored or brittle?):

Fuses, Disconnects, Protection Devices:

Problems or Damage:

Final Notes \& Observations: 
Test Report - Part 2 - Comparison of Specifications \& Results

Brief System Description \& Sketch:

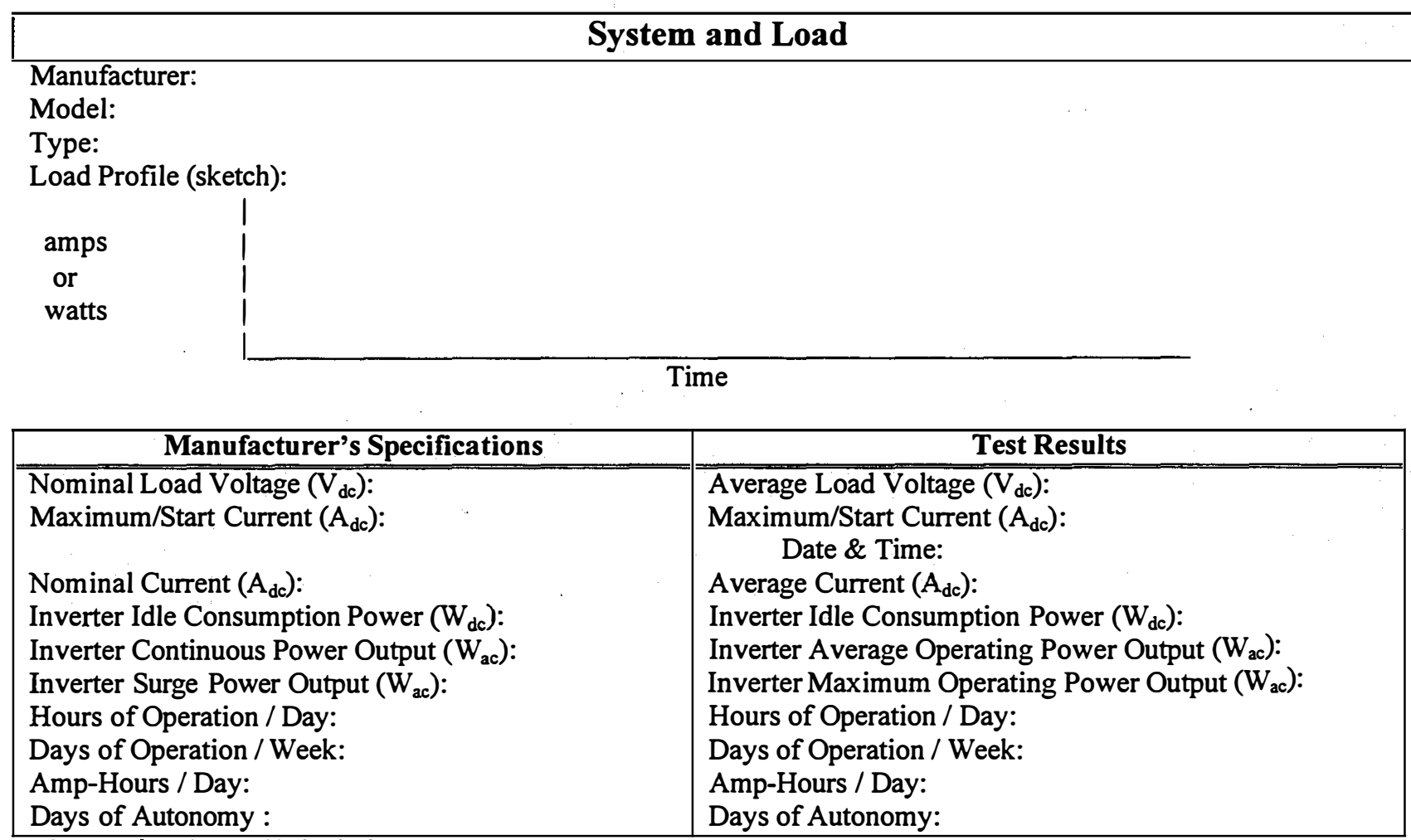

Observations/Notes/Calculations:

\section{PV Array}

Module Manufacturer:

Module Model:

Module Material:

Array Configuration (\# in series): $\quad$ (\# in parallel):

\begin{tabular}{|l|l|}
\hline \multicolumn{1}{|c|}{ Manufacturer's Specifications } & Test Results \\
\hline Rated Power $(\mathrm{W}):$ & Maximum Operating Power $(\mathrm{W}):$ \\
Voltage @ Pmax $(\mathrm{V}):$ & Voltage @ Max Operating Power $(\mathrm{V}):$ \\
Module Temperature $\left({ }^{\circ} \mathrm{C}\right):$ & Module Temperature $\left({ }^{\circ} \mathrm{C}\right):$ \\
Current @ Pmax $(\mathrm{A}):$ & Current @ Max Operating Power $(\mathrm{A}):$ \\
POA Irradiance $\left(\mathrm{W} / \mathrm{m}^{2}\right):$ & POA Irradiance $\left(\mathrm{W} / \mathrm{m}^{2}\right):$ \\
& Date \& Time: \\
Open-Circuit Voltage $(\mathrm{V}):$ & Array Maximum Operating Voltage $(\mathrm{V}):$ \\
Module Temperature $\left({ }^{\circ} \mathrm{C}\right):$ & Module Temperature $\left({ }^{\circ} \mathrm{C}\right):$ \\
Short-Circuit Current $(\mathrm{A}):$ & Date \& Time: \\
POA Irradiance $\left(\mathrm{W} / \mathrm{m}^{2}\right):$ & Array Maximum Operating Current $(\mathrm{A}):$ \\
& POA Irradiance $\left(\mathrm{W} / \mathrm{m}^{2}\right):$ \\
Array Tilt $\left({ }^{\circ}\right.$ range): & Date \& Time: \\
& Array Tilt $\left({ }^{\circ}\right):$ \\
\hline
\end{tabular}

Observations/Notes/Calculations: 


\begin{tabular}{|c|c|}
\hline \multicolumn{2}{|c|}{ Battery } \\
\hline $\begin{array}{l}\text { Battery Manufacturer: } \\
\text { Battery Model: } \\
\text { Battery Type: } \\
\text { Battery Configuration (\# in series): } \\
\text { Recommended Battery Initialization Charge Sequence: }\end{array}$ & (\# in parallel): \\
\hline Manufacturer's Specifications & Test Results \\
\hline $\begin{array}{l}\text { Nominal Battery Voltage }(\mathrm{V}): \\
\text { Nominal Cell Voltage }(\mathrm{V}): \\
\text { Nominal Capacity }(\mathrm{Ah}): \\
\text { Discharge Rate }(\mathrm{A}): \\
\text { Battery Temperature }\left({ }^{\circ} \mathrm{C}\right): \\
\text { Charge Voltage }(\mathrm{V}): \\
\text { Battery Temperature }\left({ }^{\circ} \mathrm{C}\right): \\
\text { Equalization Voltage }(\mathrm{V}): \\
\\
\text { Low-Voltage Disconnect }(\mathrm{V}): \\
\text { Discharge Rate }(\mathrm{A}):\end{array}$ & $\begin{array}{l}\text { Initial Battery Voltage }(\mathrm{V}): \\
\text { Date \& Time: } \\
\text { Initial Battery/Cell Voltage }(\mathrm{V}): \\
\text { Battery Capacity (Ah): } \\
\text { Average Current Draw }(\mathrm{A}) \\
\text { Average Battery Temperature }\left({ }^{\circ} \mathrm{C}\right) \text { : } \\
\text { Battery Average Charging Voltage }(\mathrm{V}) \text { : } \\
\text { Average Temperature }\left({ }^{\circ} \mathrm{C}\right): \\
\text { Battery Maximum Voltage }(\mathrm{V}): \\
\text { Battery Temperature }\left({ }^{\circ} \mathrm{C}\right): \\
\text { Date \& Time: } \\
\text { Battery Minimum Voltage }(\mathrm{V}): \\
\text { Discharge Current }(\mathrm{A}): \\
\text { Battery Temperature }\left({ }^{\circ} \mathrm{C}\right): \\
\text { Date \& Time: }\end{array}$ \\
\hline
\end{tabular}

Observations/Notes/Calculations:

\section{Charge Controller}

Manufacturer:

Model:

Type:

Recommended Controller Connection Sequence:

Reverse Polarity Protection ( $Y / N)$ :

\begin{tabular}{|l|l|}
\hline \multicolumn{1}{|c|}{ Manufacturer's Specifications } & \multicolumn{1}{c|}{ Test Results } \\
\hline Maximum Input Voltage (V): & Array Maximum Voltage (V): \\
Maximum Input Current (A): & Array Maximum Current (+A): \\
& \multicolumn{1}{c|}{ Date \& Time: } \\
Maximum Load Current (A): & Load Maximum Current (-A): \\
& \multicolumn{1}{c|}{ Date \& Time: } \\
Low-Voltage Disconnect (V): & Low-Voltage Disconnect (V): \\
Array Disconnect Voltage (V): & Array Disconnect Voltage (V): \\
No-Load Power Consumption (W): & No-Load Power Consumption (W): \\
TC Coefficient (V/ $\left.{ }^{\circ} \mathrm{C}\right):$ & TC Coefficient $\left(\mathrm{V} /{ }^{\circ} \mathrm{C}\right):$ \\
TC Sensor (Internal or External): & \\
\hline
\end{tabular}

Observatıons/Notes/Calculatıons: 


\subsection{References}

1. The IEEE Standard Dictionary of Electrical and Electronic Terms. ANSI/IEEE Standard 100-1992, New York, NY: The Institute of Electrical and Electronic Engineers (IEEE).

2. Recommended Practice for Maintenance, Testing, and Replacement of Large Lead Storage Batteries for Generating Stations and Substations. ANSI/IEEE Standard 450-1987, New York, NY: The Institute of Electrical and Electronic Engineers (IEEE).

3. Maintenance and Operation of Stand-Alone Photovoltaic Systems. December 1991, Albuquerque, NM: Photovoltaic Design Assistance Center, Sandia National Laboratories.

4. Photovoltaic System Design. Course Manual. 1991, Cocoa, FL: Florida Solar Energy Center.

5. Stand-Alone Photovoltaic Systems: A Handbook of Recommended Design Practices. March 1995, Albuquerque, NM: Photovoltaic Design Assistance Center, Sandia National Laboratories.

6. Storage Battery Technical Service Manual. $10^{\text {th }}$ Edition. 1987, Chicago, IL: Battery Council International.

7. Perez, Richard. The Complete Battery Book. 1985, Blue Ridge Summit, PA: Tab Books. 
Public reporting burden for this collection of Information is estimoted to overoge I hour per response, Including the fime for reviewing instructions, searching existing dota sources, gathering and malntaining the data needed, and completing and reviewing the collection of Informotion. Send cormments regarding this burden estimate or any other aspect of this collection of Informotion, Including suggestions for reducing this burden, to Washington Headquariers Services, Directorate for informotion Operations and Reports, 1215 Jefferson Dovis Highwoy, Suite 1204, Allington, VA 22202-4302, and to the Offlce of Manogernent and Budget, Papenwork Reduction Project (0704-0188), Washington. DC 20503.

\begin{tabular}{|l|l|l|}
\hline 1. AGENCY USE ONLY (LeOve blank) & $\begin{array}{l}\text { 2. REPORT DATE } \\
\text { July } 1998\end{array}$ & $\begin{array}{l}\text { 3. REPORT TYPE AND DATES COVERED } \\
\text { Technical Report }\end{array}$ \\
\hline
\end{tabular}

4. TILE AND SUBTITLE

Interim Test Methods and Procedures for Determining the Performance of Small Photovoltaic Systems

5. FUNDING NUMBERS

6. AUTHOR(S)

P. McNutt, B. Kroposki, R. Hansen, and R. DeBlasio

7. PERFORMING ORGANIZATION NAME(S) AND ADDRESS(ES)

National Renewable Energy Laboratory

1617 Cole Blvd.

Golden, CO 80401-3393

TA: PV806301

8. PERFORMING ORGANIZATION REPORT NUMBER

9. SPONSORING/MONITORING AGENCY NAME(S) AND ADDRESS(ES)

National Renewable Energy Laboratory

1617 Cole Blvd. 10. SPONSORING/MONITORING
AGENCY REPORT NUMBER

Golden, CO 80401-3393

TP-520-25077

11. SUPPLEMENTARY NOTES

12a. DISTRIBUTIONAAVALABIUTY STATEMENT

National Technical Information Service

12b. DISTRIBUTION CODE

U.S. Department of Commerce

5285 Port Royal Road

Springfield, VA 22161

\section{ABSTRACT (MOXImum 200 words)}

The National Renewable Energy Laboratory (NREL) is developing tests and procedures that will determine if the configuration of a small photovoltaic (PV) system is suitable for its intended use, and if the system will perform as specified. The procedures are presented in this report. Development of standard test procedures will allow designers, manufacturers, system integrators, users, and independent laboratories to assess the performance of PV systems under outdoor prevailing conditions. The IEEE Standards Coordinating Committee 21 (SCC21) has established a project on this subject. These procedures will be submitted to the IEEE SCC21 and International Electrotechnical Commission Technical Committee 82 (IEC TC82) for consideration as a consensus standard. Certification bodies such as PowerMark and PV Global Approval Program (PVGAP) may adopt the IEC and IEEE documents when testing systems. Developing standardized test methods and procedures at NREL to evaluate the outdoor performance of PV systems will encourage product quality and promote PV standards development. Standardized tests will assure people that PV systems will perform as specified for their intended applications. As confidence in PV systems increases, the successful commercialization of PV will grow internationally.

14. SUBJECT TERMS

photovoltaics ; photovoltaic systems ; test procedures ; system performance
15. NUMBER OF PAGES

\section{4}

16. PRICE CODE

20. LMMITATION OF ABSTRACT

UL

\begin{tabular}{|l|l|l|}
\hline $\begin{array}{l}\text { 17. SECURITY CLASSIFICATION } \\
\text { OF REPORT } \\
\text { Unclassified }\end{array}$ & $\begin{array}{c}\text { 18. SECURITY CLASSIFICATION } \\
\text { OF THIS PAGE } \\
\text { Unclassified }\end{array}$ & $\begin{array}{l}\text { 19. SECURITY CLASSIFICATION } \\
\text { OF ABSTRACT } \\
\text { Unclassified }\end{array}$ \\
\hline
\end{tabular}

Standard Form 298 (Rev. 2-89) Prescribed by ANSI Std. 239-18 